 \\ 1(2): $102-110$
}

doi: $10.3846 /$ skt.2009.13

\section{HIDROTECHNINIS BETONAS SU VIETINIAIS UŽPILDAIS IR JO NAUDOJIMAS MONOLITINIAMS STATINIAMS}

\author{
Vigantas Antanas Žiogas ${ }^{1}$, Svajūnas Juočiūnas², Giedrius Žiogas ${ }^{3}$ \\ ${ }^{1,2}$ Kauno technologijos universitetas, Studentu g. 48, LT-51367 Kaunas, Lietuva \\ ${ }^{3} A B$,Pramprojektas“, K. Donelaičio g. 60, LT-44248 Kaunas, Lietuva \\ El.paštas: ${ }^{1}$ vigantas.ziogas@ktu.lt; ${ }^{2}$ svajunas.juociunas@ktu.lt; ${ }^{3}$ ziogas.giedrius@gmail.com
}

Iteikta 200905 21; priimta 20090617

\begin{abstract}
Santrauka. Straipsnyje nagrinejjami hidrotechninių monolitinių betoninių statinių statybos technologijos ypatumai, vietinių užpildų naudojimo galimybės šių betonų gamybai, betonų nepralaidumo vandeniui nustatymo metodai bei jų vertinimas. Išnagrinèti vandens valymo įrenginių aukštų sienučių statybos technologijos ypatumai ir galimi technologiniai-organizaciniai sprendimai. Atlikta aukštų rezervuaro sienučių galimų betonavimo būdų ir nenutrūkstamos betonavimo technologijos procesų reguliuojančių parametrų bei jų sąveikos analizè. Pateiktos priklausomybès nenutrūkstamo betonavimo apimtims ir leistiniems betonuojamų segmentų ilgiams apskaičiuoti, ịvertinant betono struktūros intensyvaus formavimosi pradžią, klodų skaičių betonuojamos sienutės aukštyje ir betonavimo intensyvumą.

Reikšminiai žodžiai: hidrotechninis betonas, vietiniai užpildai, betono nepralaidumas vandeniui, betono struktūra, nenutrūkstamo betonavimo technologija, vandens valymo įrenginiai, aukštos rezervuaro sienutės.
\end{abstract}

\section{Ivadas}

Pastaruoju laikotarpiu Lietuvoje statoma ịvairios paskirties sudettingų objektų. Jų statybai reikia papildomų teorinių tyrimų parenkant tinkamas medžiagas, projektuojant betono sudètis ir kuriant bei pritaikant pažangias ir sparčias statybos technologijas. Statybos technologiniai ir organizaciniai sprendimai ivvairios paskirties objektuose būna išskirtiniai. Daugelį metų KTU Statybos technologijų katedra bendradarbiauja su statybos organizacijomis, ruošia joms naujas statybos technologijas ir padeda spręsti kilusias problemas. Sprendžiami vandens nuotekų valymo įrenginių, radioaktyviųjų atliekų laikino sandèliavimo, chemijos pramonès, transporto ir jūros uosto statinių statybose kilę klausimai (Žiogas 1995; Žiogas, Žilinskaite 2005; Žiogas, Juočiūnas 2006). Taip pat sprendžiami betonų modifikavimo šiuolaikiniais superplastikliais ir armavimo įvairiu pluoštu klausimai (Žiogas, Juočiūnas 2005). Nustatoma tokių betonų naudojimo technologija ir tikslingumas, ịvertinant statybos technologijos spartą bei būsimas konstrukcijų eksploatavimo sąlygas.
Daugelyje objektų kyla problemų įrengiant (betonuojant) masyvias gelžbetonines konstrukcijas. Masyvių gelžbetoninių konstrukcijų nenutrūkstamo betonavimo technologijoms diegti reikia atitinkamo teorinio ir techninio pasirengimo. Reikia spręsti temperatūrų ir deformacijų pokyčių poveikị masyvioje konstrukcijoje, reglamentuoti betono sudètis, betonavimo technologiją ir atitinkamą priežiūrą kietèjimo metu (Gutsch, Laube 2002; Hosoda, Kishi 2002; Durable... 1991; Žiogas, Juočiūnas 2007; Nasir Amin et al. 2008; Seyed-Hassan et al. 2007; ACI 207.2R-95. 1995).

\section{Techniniai ir technologiniai reikalavimai medžiagoms ir betonams}

Statant specialios paskirties monolitinius statinius, tenka deramą dèmesị skirti vietinių užpildų naudojimo galimybèms, parinkti tinkamą cemento atmainą ir suprojektuoti betono mišinius atitinkamai betonavimo technologijai. Statant tokius statinius, kyla papildomų reikalavimų betonavimo technologijai, betono mišiniams ir betono savybèms. Statyboms naudojami liejūs 
betono mišiniai, o betonas turi atitikti aukštus vandens nepralaidumo, atsparumo šalčiui bei padidinto agresyvumo vandens poveikio reikalavimus. Svarbią reikšmę šių rodiklių užtikrinimui turi užpildų atitiktis keliamiems techniniams reikalavimams.

Naudojant liejus betono mišinius, užpildai turi atitikti šiuos granuliometrijos reikalavimus: užpildų mišinyje smèlio frakcija iki $1,25 \mathrm{~mm}$ dydžio turi sudaryti $25-35 \%$, o frakcija, mažesnè už $0,16 \mathrm{~mm},-3-5 \%$. Tiekiant betono mišini siurbliais, rekomenduojama, kad naudojamame smèlyje frakcija $0,16-0,315 \mathrm{~mm}$ sudarytų apie $25 \%$.

Stambiuose užpilduose (frakcija $4 / 16 \mathrm{~mm}$ ) turi būti maksimalus stambesniosios frakcijos $(8 / 16 \mathrm{~mm})$ kiekis, t. y. 65-70 \%.

Naudojant užpildus, atitinkančius šiuos reikalavimus arba nežymiai jų netenkinančius, betono mišiniai gaunami tinkamų technologinių parametrų, betonas pasiekia reikalingą stiprị ir vandens nepralaidumą, tačiau išryškejja silpnų dalelių, esančių žvirgždo skaldoje, įtaka betono atsparumui šalčiui. Pagal šiuolaikinius reikalavimus silpnų dalelių kiekis skaldoje, naudojamoje hidrotechniniams betonams, neturi viršyti $5 \%$, o skaldos atsparumas šalčiui turi būti F 100, kai respublikos šalčiausio mènesio vidutinè temperatūra yra iki $-10^{\circ} \mathrm{C}$. Kai šalčiausio mènesio vidutinè temperatūra nuo $-10{ }^{\circ} \mathrm{C}$ iki $-20^{\circ} \mathrm{C}$, skaldos atsparumas šalčiui yra F 200.

Šiuo metu užpildų atsparumas šalčiui nediferencijuotas pagal hidrotechninio betono eksploatacijos sąlygas, o V/C santykis diferencijuotas priklausomai nuo betono eksploatacijos sąlygu ir reikalaujamo atsparumo šalčiui. Vadovaujantis šiuo metu naudojamų standartų reikalavimais, negalima daugumos vietinių stambių užpildų naudoti hidrotechnineje statyboje.

Dèl žvirgždo skaldos galimybių diferencijuotai naudoti hidrotechninių statinių statyboje (konstrukcijose po vandeniu ir po žeme, vandens lygio kitimo zonoje ir virš vandens) atlikti skaldos ir betonų su ja specialūs tyrimai.

Toliau pateikiami mūsų atliktų žvirgždo skaldos pavyzdžių tyrimo duomenys (1 lentelè).

Skaldos atsparumas šalčiui buvo nustatomas pagal standartų reikalavimus šaldymo kameroje (2 lentelè). Tuo pačiu metu buvo nustatytas ir silpnų dalelių atsparumas šalčiui. Tam tikslui iš žvirgždo skaldos pagal standarto reikalavimus išrinktos silpnos dalelès ir atitinkami jų kiekiai cikliškai šaldomi ir atšildomi (3 lentelè).

Pagal 2 lentelès tyrimo duomenis žvirgždo skaldos atsparumo šalčiui markè F 50. Pagal 3 lentelès tyrimo duomenis atrinktos silpnos dalelès po 50 ciklų praranda apie $25 \%$ masès. Tai reiškia, kad šaldant žvirgždo skaldą (2 lentelè) faktiškai silpnų dalelių masės nuostoliai nuo bendros užpildų masès yra nedideli ir visuminiai skaldos masès nuostoliai gaunami dèl skaldytų dalelių mikroịtrūkių. Tokios dalelès su mikroplyšiais praktiškai neturi itakos betono atsparumui šalčiui iki F 200.

1 lentelè. Žvirgždo skaldos fr. 4/16 tyrimo duomenys

Table 1. Crushed gravel fraction $4 / 16$ research data

\begin{tabular}{|c|c|c|c|c|}
\hline \multirow{2}{*}{$\begin{array}{c}\text { Band. } \\
\text { Nr. }\end{array}$} & \multicolumn{3}{|c|}{ Pilna liekana \% ant sietų } & Silpnų dalelių \\
\cline { 2 - 5 } & $D_{\max }$ & $0,5\left(D_{\max } \div D_{\min }\right)$ & $D_{\min }$ & kiekis, \% \\
\hline 1 & 2 & 3 & 4 & 5 \\
\hline 1 & 9,5 & 73,3 & 95,3 & 8,8 \\
2 & 9,9 & 82,8 & 96,4 & 5,25 \\
3 & 8,7 & 78,7 & 95,7 & 4,32 \\
4 & 9,7 & 74,7 & 98,7 & 5,4 \\
5 & 11,45 & 50,25 & 85,15 & 4,69 \\
\hline
\end{tabular}

2 lentelè. Žvirgždo skaldos atsparumas šalčiui

Table 2. Crushed gravel frost resistance

\begin{tabular}{|c|c|c|c|c|c|c|}
\hline $\begin{array}{c}\text { Band. } \\
\text { Nr. }\end{array}$ & $\begin{array}{c}\text { Frak- } \\
\text { cija, } \\
\text { mm }\end{array}$ & $\begin{array}{c}\text { Mase } \\
\text { prieš } \\
\text { bandy- } \\
\text { mą, g }\end{array}$ & $\begin{array}{c}\text { Šaldy- } \\
\text { mo ir } \\
\text { atšil- } \\
\text { dymo } \\
\text { ciklų sk. }\end{array}$ & $\begin{array}{c}\text { Masè } \\
\text { po } \\
\text { bandy- } \\
\text { mo }\end{array}$ & $\begin{array}{c}\text { Masès } \\
\text { nuos- } \\
\text { toliai, } \\
\%\end{array}$ & $\begin{array}{c}\text { Atspa- } \\
\text { rumo } \\
\text { šalčiui } \\
\text { marke் }\end{array}$ \\
\hline 1 & $4 / 8$ & 1000 & 50 & 960 & 4,0 & \\
2 & $4 / 8$ & 1000 & 50 & 950 & 5,0 & \\
3 & $8 / 6$ & 1500 & 50 & 1430 & 4,66 & F 50 \\
4 & $8 / 16$ & 1500 & 50 & 1425 & 5,0 & \\
\hline
\end{tabular}

3 lentelè. Atrinktų silpnų dalelių atsparumas šalčiui

Table 3. Frost resistance of selected weak particles

\begin{tabular}{|c|c|c|c|c|c|}
\hline Frak- & \multirow{2}{*}{$\begin{array}{c}\text { Sauso } \\
\text { cija, } \\
\text { mm }\end{array}$} & $\begin{array}{c}\text { Vandens } \\
\text { dinio }\end{array}$ & $\begin{array}{c}\text { igeriamu- } \\
\text { mo \% po } \\
\text { masè, g }\end{array}$ & $48 \mathrm{~h}$ & \multicolumn{3}{|c|}{$\begin{array}{c}\text { Masės nuostoliai po šaldymo } \\
\text { ir šildymo ciklų }\end{array}$} \\
\cline { 4 - 6 } & & $\begin{array}{c}\text { po 25 } \\
\text { ciklų }\end{array}$ & $\begin{array}{c}\text { po 50 } \\
\text { ciklų }\end{array}$ & $\begin{array}{c}\text { po 75 } \\
\text { ciklų }\end{array}$ \\
\hline $4 / 8$ & 300 & 5,0 & 16,6 & 27,1 & 33,6 \\
\hline $8 / 16$ & 700 & 5,0 & 13,6 & 24,0 & 30,5 \\
\hline $\begin{array}{c}\text { Vidu- } \\
\text { tiniai } \\
\text { poky- } \\
\text { čiai }\end{array}$ & & 5,0 & 14,5 & 25,5 & 32,5 \\
\hline
\end{tabular}

Remdamiesi 3 lentelès tyrimo duomenimis ir teigdami, kad ant sieto $0,5\left(D_{\max } \div D_{\min }\right)$ liekana sudaro 70 $\%$, silpnų dalelių skaldoje yra 5; 7,5; $10 \%$ (atitinkamai frakcijose $4 / 8$ ir $8 / 16 \mathrm{~mm}$ santykiu $2: 1$ ), apskaičiuoti žvirgždo skaldos nuostoliai šaldant ir kokiai markei pagal atsparumą šalčiui skaldą galima priskirti (4 lentele). 
4 lentelè. Apskaičiuoti žvirgždo skaldos masès nuostoliai šaldant

Table 4. Calculated crushed gravel mass loss when subjected to freezing

\begin{tabular}{|c|c|c|c|c|}
\hline \multirow{2}{*}{$\begin{array}{c}\text { Esant silpnų } \\
\text { dalelių, \% }\end{array}$} & \multicolumn{4}{|c|}{ Nuostoliai \% po šaldymo ir šildymo ciklų } \\
\cline { 2 - 5 } & $\begin{array}{c}\text { po } 25 \\
\text { ciklų }\end{array}$ & $\begin{array}{c}\text { po } 50 \\
\text { ciklų }\end{array}$ & $\begin{array}{c}\text { po } 75 \\
\text { ciklų }\end{array}$ & $\begin{array}{c}\text { po } 100 \\
\text { ciklų }\end{array}$ \\
\hline 5 & 0,357 & 0,547 & 0,688 & 0,865 \\
7,5 & 0,487 & 0,826 & 0,990 & 1,20 \\
10 & 0,664 & 1,25 & 1,42 & 1,65 \\
\hline
\end{tabular}

Nuostoliai $\Delta m$ po atitinkamo šaldymo ciklų skaičiaus surandami:

$\Delta m=\frac{a_{I s} \cdot m_{I \check{s}}}{100} \cdot n_{I}+\frac{m_{2 g} \cdot m_{2 \check{s}}}{100} \cdot n_{2}$,

čia: $m_{I s}-$ silpnų dalelių kiekis, frakcijoje $4 / 8 \mathrm{~mm} ; m_{I \breve{s}}-$ frakcijos $4 / 8 \mathrm{~mm}$ silpnų dalelių kasès nuostoliai šaldant; $n_{I}-$ frakcijos $4 / 8 \mathrm{~mm}$ kiekis vieneto dalimis užpildų mišinyje; $m_{2 s}, m_{2 \check{s}}$ ir $n_{2}$ analogiškai frakcijai $8 / 16 \mathrm{~mm}$.

Iš tyrimų, atliktų pagal šią metodiką, matome, kad žvirgždo skalda atitinka atsparumo šalčiui reikalavimus.

Naudojant tirto karjero užpildus buvo suformuoti betono bandiniai (liejus betono mišinys, skirtas hidrotechninei statybai) ir po 28 parų kietejimo atlikti šaldymo ir atšildymo ciklai. Vidiniai betono struktūros pakitimai periodiškai buvo sekami ultragarsu.

Tiriant betono bandinių atsparumą šalčiui, pastebèta, kad po 15-50 ciklų pradeda išbyrèti paviršiuje esančios silpnos dalelès (mergelingas ir sucementuotas smiltainis). Pavojingesni yra stambiosios frakcijos $(8 / 16 \mathrm{~mm})$ silpnieji užpildai. Betonų struktūros didesnių pokyčių, matuojant ultragarso sklidimo greitị po 50, 100, 150 ir 200 ciklų, nepastebèta, atsparumo šalčiui koeficientas $K_{\check{s}}>\mathrm{I}$.

Kai silpnų dalelių kiekis neviršija $5 \%$ ir tame kiekyje mergelingo ir sucementuoto smiltainio dalelès tesudaro apie trečdali, tyrimo metu nepasitaikè betono paviršiaus suardymo atvejų dẻl silpnų dalelių išbyrejjimo cikliškai šaldant betoną. Atlikus tyrimo duomenų analizę galima apibendrinti:

- žvirgždo skaldą rekomenduojama naudoti vandens valymo ịrenginių požeminių ir kitų konstrukcijų betonams, kurių neveikia kintamas vandens lygis ir nevyksta vandens perpylimas;

- žvirgždo skaldos atsparumo šalčiui markę ir jos tinkamumą hidrotechniniams betonams rekomenduojame nustatyti, ịvertinant silpnų dalelių kiekị ir jų atsparumą šalčiui;

- standartuose reikètų numatyti diferencijuotą vietinès skaldos naudojimą hidrotechniniams betonams, ịvertinant jų eksploatacijos sąlygas.
Statant specialiosios paskirties monolitinius statinius, dažnai reikia naudoti nelaidžius vandeniui betonus. Betonų nelaidumas vandeniui yra vienas iš svarbių veiksnių, nusakančių betonų ilgalaikiškumą. Betonų nelaidumas vandeniui, taip pat ir ilgalaikiškumas priklauso nuo suformuotos struktūros. Betono struktūra pradeda formuotis sumaišius betono mišinị, ji baigia formuotis kietejjimo metu ir, priklausomai nuo aplinkos poveikio, kinta eksploatacijos metu.

Betonų nelaidumas vandeniui reglamentuojamas toms gelžbetoninèms konstrukcijoms, kurios sąveikauja su vandeniu arba yra veikiamos drégnos agresyviosios aplinkos.

Priklausomai nuo konstrukcijos paskirties ir eksploatacijos sąlygu praktikoje naudojamos šios nepralaidumo vandeniui markès: W2, W4, W6, W8, W10, W12. Betonų nepralaidumo vandeniui marke konkrečioms konstrukcijoms nustatoma atsižvelgiant ị reikalavimus padidintam tankiui, nepralaidumui ir atsparumui korozijai. Konkreti nepralaidumo vandeniui markè nustatoma pagal projektavimo normas, standartus ir technines sąlygas.

Pagal statybos normas ir taisykles, priklausomai nuo aplinkos agresyvumo laipsnio ir panaudotos armatūrinio plieno grupès, gelžbetoninių konstrukcijų betonas turi atitikti W4, W6 ar W8 nepralaidumo vandeniui markes. Silpnai agresyvioje aplinkoje naudojamas W4 markès betonas, o stipriai agresyvioje aplinkoje W8 nepralaidumo markés betonai.

Šiuo metu betonai pagal LST EN 206-1 standartą skirstomi ì nepralaidžius ir pralaidžius vandeniui. Betonas nepralaidus vandeniui, kai vidutinis įsiskverbimo gylis, bandant pagal LST EN 12390-8, yra mažesnis negu $20 \mathrm{~mm}$, o didžiausia reikšmé neviršija 50 $\mathrm{mm}$. Nelaidaus vandeniui betono vandens cemento santykis turi neviršyti 0,55. Pažymètina, kad eksploatacijos metu vandenyje plyšiai betone savaime užsitraukia ir betonas tampa labiau nepralaidus vandeniui (Corola... 1996) ir atsparesnis korozijai (Матвиенко et al. 1984).

Pagal švedų betonų asociacijos rekomendacijas (Durable... 1991) iš betonų nebus išplaunami $\mathrm{Ca}(\mathrm{OH})_{2}$ junginiai, kai betono nelaidumas vandeniui neviršys $10^{-11} \mathrm{~m} / \mathrm{s}$. Tokie betonai atitiks B2/A2 naudojimo aplinkos sąlygų kategorijos reikalavimus. Pagal LST 1974:2005 tai turètų būti markè $W>4\left(2 \cdot 10^{-9}\right.$ $7 \cdot 10^{-9} \mathrm{~m} / \mathrm{s}$ ).

Galiojant griežtesnėms B3/A3 eksploatacijos sąlygoms, betono nelaidumas turi neviršyti $10^{-12} \mathrm{~m} / \mathrm{s}$ (pagal LST 1974:2005 tai būtų $W \geq 10$ ). 
Ivairios paskirties statnių projektuose betonų nepralaidumas reglamentuojamas nepralaidumo marke arba betono pralaidumo rodikliu (pagal LST EN 2061). Betonų nepralaidumo markès ir pralaidumo rodiklio naudojimas sukelia keblumų projektuotojams ir statybos objektų vykdytojams, nes iki šiol nèra nustatytų analitinių priklausomybių ir eksperimentinių lyginimų tarp šių dydžių. Be to, nepralaidumo ir pralaidumo terminai dažnai neatitinka faktinès padèties tiriant betono savybes šiais minètais metodais.

Gelžbetoninems konstrukcijoms, betono gaminiams ir prekiniam betonui sertifikuoti respublikoje šiuo metu taikomi du betono nepralaidumo vandeniui nustatymo būdai, tai LST 1974:2005 „drègnos dèmès“ metodas ir LST EN 12390-8 vandens ịsiskverbimo gylio metodas.

\section{Bandiniai tyrimams ir bandymo režimai}

Lyginamiesiems tyrimams buvo panaudoti ịvairių betono sudèčiu (su skirtinga cemento atmaina, mažų, vidutinių ir aukštų stiprio klasių betonai, betonai su nepralaidumą vandeniui didinančiais priedais, suformuoti iš plastiškų ir liejų betono mišinių), standartiniai bandiniai - cilindrai $150 \mathrm{~mm}$ skersmens ir $150 \mathrm{~mm}$ aukščio. 1 pav.

Tyrimai buvo atliekami pagal režimus, pateiktus

Bandant bandinius iki 0,8 $\mathrm{MPa}$ (W8 nepralaidumo markè), slègio ir laiko sandaugų suma $\Sigma \mathrm{P} \cdot \mathrm{T}=$ 32 ir tai atima bandymo pagal LST EN 12390-8 reži-

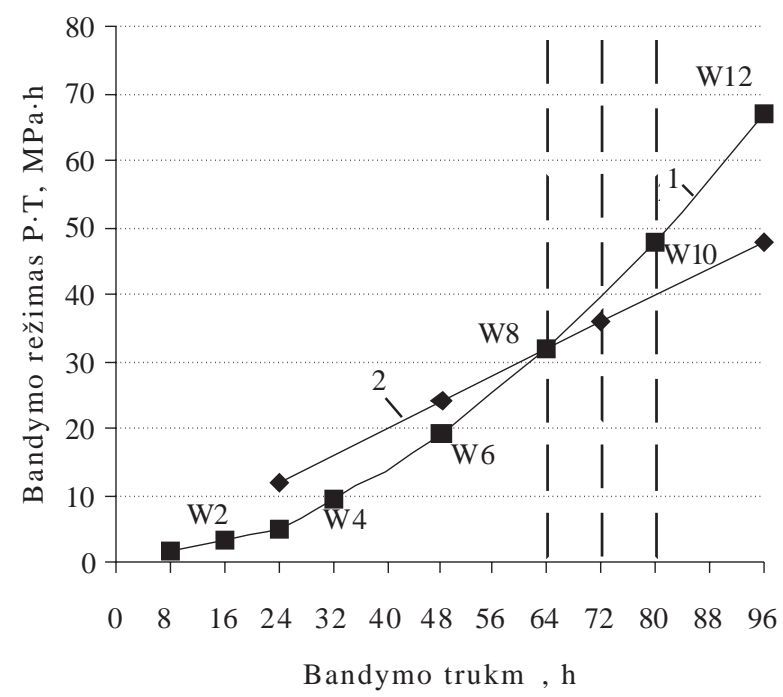

1 pav. Bandymų režimų kreivės pagal LST 1974:2005 (1 kreivė) ir LST EN 12390-8 (2 kreivè)

Fig. 1. Experimental mode graphs according to LST 1974:2005 (graph 1) and LST EN 12390-8 (graph 2) mui $-\Sigma$ P.T $=36$. Pagal LST 1974:2005 bandymo trukmè $8 \mathrm{~h}$ trumpesnè už bandymo režimą pagal LST EN 12390-8.

Bandant bandinius iki 1,0 MPa slègio (W10 nepralaidumo markè), slègio ir laiko sandaugų suma $\Sigma \mathrm{P} \cdot \mathrm{T}=48$ ir bandymo trukmè $8 \mathrm{~h}$ trumpesnè už režimą pagal LST EN 12390-8. Kaip matome, bandymo režimas pagal LST EN 12390-8 yra ne toks intensyvus, o bandymo trukmè ilgesnè.

Atlikdami lyginamuosius tyrimus LST EN 123908 pagrindiniu režimu ėmème betono nepralaidumo markès W8 bandymo režimą pagal LST 1974:2005.

Remiantis mūsų atliktais tyrimais ir rekomenduojama priklausomybe (Khatri, Sirivivantnanon 1997), apskaičiuoti vandens įsiskverbimo (penetracijos) dydžiai $d$ pagal formulę:

$d^{2}=\frac{2 K_{p} \cdot T \cdot h}{V}$,

čia: $d$ - vandens įsiskverbimo gylis, $\mathrm{m} ; K_{p}$ - filtracijos koeficientas, $\mathrm{m} / \mathrm{s} ; T$ - bandymo trukmé, $\mathrm{s}$ $h$ - vandens slègis, $\mathrm{m}$; $V$ - betono poringumas, apskaičiuotas remiantis Khatri ir Sirivivantnanon (1997).

Vandens ịsiskverbimo gylis $d$ nustatytas pagal (2) priklausomybę, kai kapiliarinių porų kiekis $V_{k}$ apskaičiuotas pagal žinomą priklausomybę:

$V_{k}=\frac{V_{0}-2 \cdot W_{s} \cdot C}{1000}$

čia: $V_{0}$ - vandens kiekis $1 \mathrm{~m}^{3}$ betono mišinio; $W_{s}-$ cemento surištas vandens kiekis; $C$ - cemento kiekis, $\mathrm{kg}$ $1 \mathrm{~m}^{3}$ betono.

Apskaičiuoti vandens įsiskverbimo teoriniai gyliai pateikti 5 lentelëje.

5 lentelè. Vandens įsiskverbimo teoriniai gyliai betonuose

Table 5. Theoretical water penetration depths in concretes

\begin{tabular}{|c|c|c|c|c|c|}
\hline \multirow{2}{*}{$\begin{array}{c}\text { Betono ne- } \\
\text { pralaidumo } \\
\text { vanileniui } \\
\text { marke }\end{array}$} & \multirow{2}{*}{$\begin{array}{l}\text { Filtracijos } \\
\text { koeficien- } \\
\text { tas } K_{p}, \mathrm{~m} / \mathrm{s} \\
\text { (teorinis) }\end{array}$} & \multirow{2}{*}{$\begin{array}{c}\text { Ce- } \\
\text { mento } \\
\text { kiekis, } \\
\text { kg }\end{array}$} & \multirow{2}{*}{$\mathrm{V} / \mathrm{C}$} & \multicolumn{2}{|c|}{$\begin{array}{l}\text { Vandens įsiskverbimo } \\
\text { gylis, mm (teorinis) }\end{array}$} \\
\hline & & & & pagal (2) & $\begin{array}{l}\text { pagal (2) } \\
\text { ir (3) }\end{array}$ \\
\hline \multirow{2}{*}{ W6 } & \multirow{2}{*}{$\begin{array}{l}2 \cdot 10^{11}- \\
6 \cdot 10^{-12}\end{array}$} & \multirow{2}{*}{350} & 0,45 & $12,5-6.86$ & $22,9-12,56$ \\
\hline & & & 0,55 & $12.23-6.73$ & $15,04-8,24$ \\
\hline \multirow{2}{*}{ W8 } & \multirow{2}{*}{$\begin{array}{l}6 \cdot 10^{12}- \\
1 \cdot 10^{-12}\end{array}$} & \multirow{2}{*}{350} & 0,45 & $8,85-3,61$ & $16,21-6,62$ \\
\hline & & & 0,55 & $8,68-3,54$ & $10,63-4,34$ \\
\hline \multirow{2}{*}{ W10 } & \multirow{2}{*}{$\begin{array}{l}1 \cdot 10^{12}- \\
6 \cdot 10^{-13}\end{array}$} & \multirow{2}{*}{350} & 0,45 & $4,43-3,43$ & $8,11-6,28$ \\
\hline & & & 0,55 & $4,34-3,36$ & $5,35-4,12$ \\
\hline \multirow[b]{2}{*}{$\begin{array}{l}\text { Pagal LST } \\
\text { EN 12390-8 }\end{array}$} & \multirow{2}{*}{$\begin{array}{c}6 \cdot 10^{12}-1^{10-12} \\
\text { (imtas paly- } \\
\text { ginimui) }\end{array}$} & \multirow[b]{2}{*}{350} & 0,45 & $8,41-3,43$ & $13,7-6,3$ \\
\hline & & & 0,55 & $8,21-3,36$ & $10,1-4,12$ \\
\hline & & & & Vid. & 0 \\
\hline
\end{tabular}


Remiantis bandymo režimais ir apskaičiuotais vandens i̇siskverbimo teoriniais gyliais galima teigti, kad LST EN 12390-8 bandymas artimas betono bandymui nustatant W8 markę pagal LST 1974:2005.

\section{Betonų nepralaidumo vandeniui lyginamieji tyrimai}

Lyginamieji betonų nepralaidumo vandeniui tyrimai atlikti naudojant betonus nuo C16/20 iki C50/60 stiprio klasès. Bandiniai tyrimams suformuoti naudojant S2 ir S3 slankumo markès betono mišinius. Dalis tyrimo duomenų pateikta 6 lentelëje.

Remiantis teoriniais vandens įsiskverbimo gyliais betonuose (5 lentelè) ir eksperimentiniais tyrimais ( 6 lentelè), galima teigti, kad betonai C25/30, suformuoti iš S3 slankumo mišinių ir žemesnių stiprio klasių, yra pralaidūs vandeniui pagal LST EN 12390-8 reikalavimus. C25/30 stiprio klasès betonai gali būti ir nepralaidūs vandeniui, kai jie suformuoti iš S1 ar S2 slankumo markès mišinių ir juose naudoti plastikliai.

Teoriškai LST EN 12390-8 bandymo metodas atitinka W8 bandymo režimą pagal LST 1974:2005. Eks- perimentinių tyrimų duomenys rodo, kad betonus tikslinga bandyti pagal LST EN 12390-8 metodą, kai jų nepralaidumo markè $W \geq 8$. LST EN 12390-8 metodas pagal eksperimentinius duomenis yra artimas W10 nepralaidumo markei pagal LST 1974:2005 nustatymo metodą.

Nepralaidžių vandeniui betonų struktūros poringumo rodiklis daugelị atvejų yra 1-1,1, o aukštų nepralaidumo markių betonų $\lambda<1,0$. Struktūros poringumo rodiklis nustatomas pagal A. E. Šeikino metodiką (Шейкин et al. 1979).

Atliekant produkcijos sertifikavimą, LST EN 12390-8 pralaidumo nustatymo metodas taikytinas C25/30 ir aukštesnių gniuždomojo stiprio gniuždant klasių betonams, kurių nepralaidumo vandeniui marke $W \geq 8$. Rekomenduotina nustatyti C25/30 ir žemesnių klasių betonų, kurių $W \leq 8$, nepralaidumą vandeniui pagal LST 1974:2005

Remiantis atliktais tyrimais galima teigti, kad hidrotechninès paskirties statiniams be rekomenduojamo $40 \mathrm{~mm}$ storio apsauginio betono sluoksnio, būtina padidinti betonų nepralaidumo vandeniui reikalavimus.

6 lentelè. Betonų nepralaidumo vandeniui lyginamieji duomenys

Table 6. Comparative data of water impermeability

\begin{tabular}{|c|c|c|c|c|c|}
\hline $\begin{array}{l}\text { Eil. } \\
\text { Nr. }\end{array}$ & $\begin{array}{l}\text { Betono sti- } \\
\text { prio klasé }\end{array}$ & $\begin{array}{c}\text { Maksimalus } \\
\text { slègis, } \mathrm{MPa}\end{array}$ & $\begin{array}{l}\text { Vandens ịsiskverbimo gylis, mm, } \\
\text { ir markè pagal LST 1974:2005 }\end{array}$ & $\begin{array}{l}\text { Vandens ịsiskverbimo gylis, } \\
\text { mm, ir pralaidumo rodiklis } \\
\text { pagal LST EN } 12390-8\end{array}$ & $\begin{array}{l}\text { Betono struktūros po- } \\
\text { ringumo rodiklis } \lambda\end{array}$ \\
\hline $1(1)$ & \multirow{3}{*}{$\begin{array}{l}\mathrm{C} 16 / 20 \\
\mathrm{C} 16 / 20^{*} \\
\mathrm{C} 16 / 20\end{array}$} & 0,6 & 133, W6 & \multirow{3}{*}{$\begin{array}{l}\text { 100/85, pralaidus } \\
\text { 32/20, pralaidus } \\
\text { 52/43, pralaidus }\end{array}$} & \\
\hline 2 & & 0,6 & $63, \mathrm{~W} 8$ & & \\
\hline 3 & & 0,7 & W8 & & \\
\hline 4 & \multirow{3}{*}{$\begin{array}{l}\mathrm{C} 20 / 25^{*} \\
\mathrm{C} 20 / 25\end{array}$} & \multirow{3}{*}{$\begin{array}{l}0,6 \\
0,7\end{array}$} & \multirow{3}{*}{$\begin{array}{c}35, \mathrm{~W} 8 \\
\mathrm{~W} 8\end{array}$} & \multirow{3}{*}{$\begin{array}{l}30 / 20 \text {, pralaidus } \\
77 / 60 \text {, pralaidus }\end{array}$} & \\
\hline $\begin{array}{l}4 \\
5\end{array}$ & & & & & \\
\hline & & & & & \\
\hline 6 & \multirow{5}{*}{$\begin{array}{c}\mathrm{C} 25 / 30^{*} \\
\mathrm{C} 25 / 30 \\
\mathrm{C} 25 / 30^{*} \\
\mathrm{C} 25 / 30 \\
\mathrm{C} 25 / 30^{*}\end{array}$} & 0,6 & $40, W>8$ & \multirow{5}{*}{$\begin{array}{c}\text { 30/17, nepralaidus } 45 / 40, \text { pra- } \\
\text { laidus } \\
50 / 33 \text {, pralaidus } \\
\text { pralaidus } \\
\text { 85/82, pralaidus }\end{array}$} & \\
\hline 7 & & 0,7 & $\mathrm{~W}>8$ & & \\
\hline 8 & & 0,7 & $\mathrm{~W}>8$ & & \\
\hline $9(1)$ & & 0,8 & $52, W>8$ & & 1,31 \\
\hline $10(1)$ & & 0,8 & $130, \mathrm{~W} 8$ & & 1,37 \\
\hline 11 & \multirow{5}{*}{$\begin{array}{c}\mathrm{C} 30 / 37^{\star} \\
\mathrm{C} 30 / 37^{\star} \\
\mathrm{C} 30 / 37 \\
\mathrm{C} 30 / 37^{\star} \\
\mathrm{C} 30 / 37\end{array}$} & 0,7 & $\mathrm{~W}>10$ & \multirow{5}{*}{$\begin{array}{c}19 / 15, \text { nepralaidus } \\
11.4 / 9 \text {, nepralaidus } \\
25 / 18 \text {, nepralaidus } 80 / 60 \text {, pra- } \\
\text { laidus } \\
\text { pralaidus }\end{array}$} & \multirow[b]{5}{*}{1,03} \\
\hline 12 & & 0,7 & $\mathrm{~W}>10$ & & \\
\hline 13 & & 0,8 & $\mathrm{~W} \geq 10$ & & \\
\hline $14(1)$ & & 0,8 & $94, \mathrm{~W} 8$ & & \\
\hline $15(1)$ & & 0,8 & 80 , W8 & & \\
\hline 16 & \multirow{3}{*}{$\begin{array}{l}\mathrm{C} 35 / 45 \\
\mathrm{C} 35 / 45^{*} \\
\mathrm{C} 35 / 45^{*}\end{array}$} & 0,8 & $15-20, \mathrm{~W} 10$ & \multirow{3}{*}{$\begin{array}{c}\text { nepralaidus } \\
19 / 16 \text {, nepralaidus } 11,5 / 9, \text { ne- } \\
\text { pralaidus nepralaidus }\end{array}$} & 0,932 \\
\hline 17 & & 0,7 & $\mathrm{~W}>10$ & & 1,06 \\
\hline 18 & & 0,7 & $\mathrm{~W}>10$ & & 0,84 \\
\hline 19 & $\mathrm{C} 40 / 50^{* *}$ & 1,0 & $\mathrm{~W}>10$ & $10 / 5$, nepralaidus & 0,937 \\
\hline 20 & $\mathrm{C} 50 / 60^{* *}$ & 1,6 & W16 & $20 / 6$, nepralaidus & 0,652 \\
\hline
\end{tabular}

*betonai su plastiklio priedu, ${ }^{*}$ betonai su plastikliu ir $\mathrm{SiO}_{2}$ priedu, (1) - betonai iš liejų betono mišinių 
Vietoje W6 bei W8 nepralaidumo vandeniui markių betonų atskiriems hidrotechninių statinių konstruktyvams rekomenduojama projektuoti nelaidžius vandeniui betonus pagal LST EN 12390-8 reikalavimus.

Hidrotechninių betonų projektavimo pagrindinès nuostatos ir ypatumai pateikti ankstesniuose tyrimuose (Žiogas 1999).

\section{Vandens nuotekų valymo ịrenginių aukštų sienučių statybos technologijos ypatumai}

Vandens valymo irenginių statybos technologijos, jų techninis-ekonominis vertinimas nagrinètas ankstesniuose mūsų darbuose (Žiogas 1995; Žiogas, Žilinskaitè 2005; Žiogas, Juočiūnas 2006; Žiogas 1999).

Šiame straipsnyje nagrinèjami vandens biologinio valymo talpyklų ir rezervuarų, turinčių aukštas sienutes, betonavimo ypatumai ir galimi technologiniai bei organizaciniai sprendimai.

Aukštos sienutès gali būti betonuojamos šiais būdais:

1. Sienutès betonuojamos naudojant betono mišiniui kloti ir giluminių vibratorių galvutems nuleisti teleskopinius vamzdžius.

2. Aukštos sienutès betonuojamos paduodant betono mišinį ir ịkišant giluminius vibratorius per klojiniuose paruoštas angas.

3. Aukštos sienutès betonuojamos iš vienos pusès visiškai nesurenkant klojinių ir sudarant tinkamas sąlygas betono mišiniui kloti ir sutankinti. Paklojus betono mišini numatytame sienutès aukštyje, surenkami likę klojiniai ir betonavimo procesas baigiamas.

4. Sienutès betonuojamos atskirais vertikaliais segmentais, įrengiant tarp jų horizontalias siūles.

5. Nevibracinio betonavimo būdu, naudojant susitankinančius liejus betono mišinius.

Dideli vandens nuotekų biologinio valymo rezervuarai (sienučių ilgis - apie $100 \mathrm{~m}$ ) yra sudalyti temperatūrinèmis ir konstrukcinèmis-technologinèmis siūlèmis $\mathfrak{i}$ atitinkamo ilgio segmentus. Tokių rezervuarų statyba vykdoma pagal pertraukiamą segmentinę betonavimo technologiją. Atstumas tarp konstrukciniųtechnologinių siūlių segmentuose priklauso nuo konstrukcijos armavimo laipsnio, aplinkos temperatūros ir naudoto betono deformacinių savybių (ACI 350R-6. 2006; Žiogas, Juočiūnas 2006). Be minètų konstrukcinių sąlygų, segmento dydị lemia betonavimo darbų intensyvumas $I_{b}$, betono mišinio slègis ị klojinius ir sukloto betono mišinio kietėjimo kinetika (betono struktūros intensyvaus formavimosi pradžia $t_{s t . f}$ ).
Galima betonuojamo segmento apimtis $\left(\mathrm{m}^{3}\right) \mathrm{nu}-$ statoma taip:

$Q=I_{b} \cdot t_{s t . f}$.

Kai rezervuaro sienučių aukštis daugiau kaip $4 \mathrm{~m}$, būtina ịrengti sandarią horizontalią siūlę ir sienutę betonuoti dviem etapais. Aukštos sienutès betonavimas dviem etapais sumažina darbų spartą (apatinis klodas turi pasiekti $(0,3-0,5) R_{p r}$ ir tik tada galima montuoti viršutinès dalies klojinius bei detonuoti), reikia įrengti brangiai kainuojančią horizontalią siūlę ir ją kokybiškai sujungti su vertikalia sandarinamaja segmento juosta, pailgejja darbų atlikimo trukmè. Be to, padidèja darbo sąnaudos klojiniams įrengti (nuo $0,245 \mathrm{žm}$. val./ $/ \mathrm{m}^{2} \mathrm{iki} 0,43 \mathrm{žm}$. val. $/ \mathrm{m}^{2}$ ). Šių problemų galima išvengti taikant nenutrūkstamo sienučių betonavimo būdą visu aukščiu. Tačiau projektuojant nenutrūkstamą betonavimo technologiją, reikia išspręsti šiuos klausimus:

- suprojektuoti šiai technologijai tinkamas betono sudètis;

- išspręsti betono mišinio padavimo ir sutankinimo technologiją žemutinëje sienutès dalyje, kad nevyktų betono mišinio segregacija klojimo metu ir sluoksniavimasis sutankinant;

- ivvertinti sukloto ir sutankinto betono mišinio slūgimo deformacijas, numatant klodų aukštị ir atitinkamas pertraukas užbetonavus klodus;

- plonesnių sienučių $(b<0,4 \mathrm{~m})$ ir esant nepakankamai standžiai surinktų klojinių sistemai (per betonuojamo segmento ilgi ir plotị), betonavimo procesas turi būti atliktas iki betono mišinio struktūros intensyvaus formavimosi pradžios $t_{\text {st.f. }}$.

Ivertinant pirmiau minètus technologinius veiksnius, betonavimo apimtis apskaičiuojama taip:

$Q=\left(t_{s t . f}-0,5\left(n_{k l .}-1\right)\right) \cdot I_{b}$.

Iš (5) priklausomybès surandame leistiną betonuojamo segmento ilgị $l_{\text {seg. }}$ :

$l_{\text {seg. }}=\frac{t_{s t . f}-0,5\left(n_{k l .}-1\right)}{b \cdot h} I_{b}$,

čia: $Q$ - betonuojamo segmento tūris, $\mathrm{m}^{3}$; $t_{\text {st.f. }}$ - betono struktūros intensyvaus formavimosi pradžia, val.; $n_{k l}$ klodų skaičius betonuojamos sienutes aukštyje; $b$ - sienutès plotis, $\mathrm{m} ; h$ - sienutés aukštis, $\mathrm{m} ; I_{b}$ - betonavimo intensyvumas, $\mathrm{m}^{3} / \mathrm{val}$.

Betonuojamos sienutès segmento ilgis neturi viršyti leistinų atstumų tarp siūlių $l_{s}$ (t. y. $l_{\text {seg. }} \leq l_{s}$ ) (ACI 350R-6. 2006). 
Betono mišini paduodant ị klojinius siurbliu, reikalingos siurblio sąnaudos imamos $0,1-0,15 \mathrm{val} . / \mathrm{m}^{3}$. Aukštoms sienutèms betonuoti siurblio darbo sąnaudos padidinamos apie $25 \%$.

Betonavimo technologijos procesą reguliuojančiu išvestinių parametrų sąveika pateikta 2 pav.

İvertinus nenutrūkstamos betonavimo technologijos techninius reikalavimus, buvo parengtos rekomendacijos Kauno miesto vandens nuotekų biologinio valymo įrenginių statybai.

Rezervuaro aukštų sienučių nenutrūkstamos betonavimo technologijos sprendimo schema pateikta 3 pav.

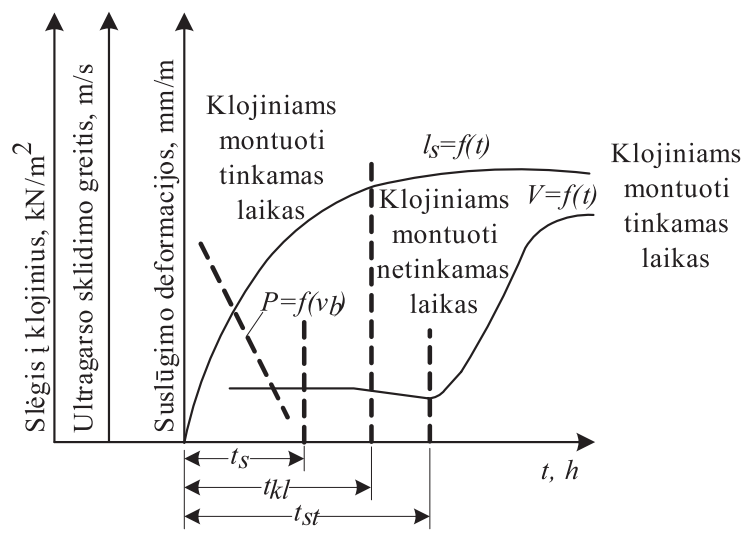

Trukmė nuo mišinio užmaišymo

2 pav. Betonavimo procesą reguliuojančių parametrų sąveika: $t_{s}$ - betono mišinio suklojimo sluoksniais trukmé; $t_{k l}$ - betono mišinio klodų intensyvaus slūgimo trukmé; $t_{s t}-$ sukloto ir sutankinto betono struktūros intensyvaus formavimosi pradžia

Fig. 2. Interaction of key parameters controlling the concreting process

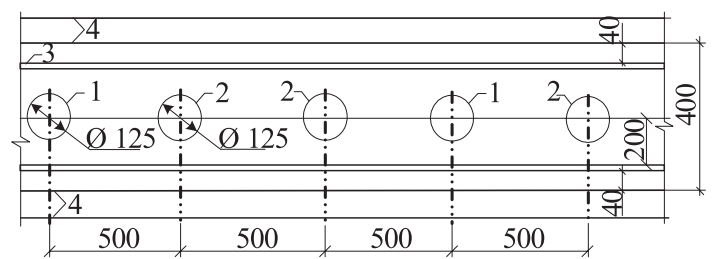

$l_{1}, l_{2} l_{3} \quad \mathrm{~h}_{\mathrm{k}}=1500$ (I ir II klodui); $\mathrm{h}_{\mathrm{k}}=2000$ (sekantiems klodams)

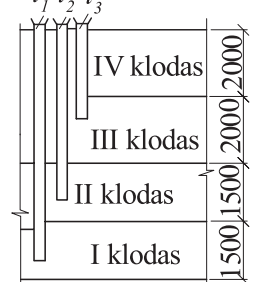

1. Plastmasinis vamzdis betono mišiniui kloti

2. Plastmasinis vamzdis vibratoriaus galvutei nuleisti

3. Armatūros strypynas

4. Klojiniai

3 pav. Aukštų sienučių betonavimas betono mišiniui kloti ir vibratoriams nuleisti naudojant plastmasinius vamzdžius

Fig. 3. Concreting high walls by means of plastic tubes for placing the mix and lowering vibrators
Reikalingas teleskopinių arba atitinkamų ilgių vamzdžiu skaičius parenkamas įvertinant betonavimo segmento ilgị $l_{\text {seg. }}$ ir aukštị $h$.

Betono mišinys klojamas teleskopiniais arba išardomais vamzdžiais, kurie išdèstomi $1,5-2 \mathrm{~m}$ atstumais. Giluminiai vibratoriai nuleidžiami i apatinę dali per vamzdžius, kurie išdèstyti įvertinant vibratorių veikimo zoną. Apatinių klodų aukštis projektuojamas iki $1,5 \mathrm{~m}$, o viršutiniu gali būti didesnis. Paskutinis klodas (IV) betonuojamas nenaudojant plastmasiniu vamzdžių. Rezervuaro aukštos sienutès nenutrūkstamas betonavimas parodytas 4 pav.

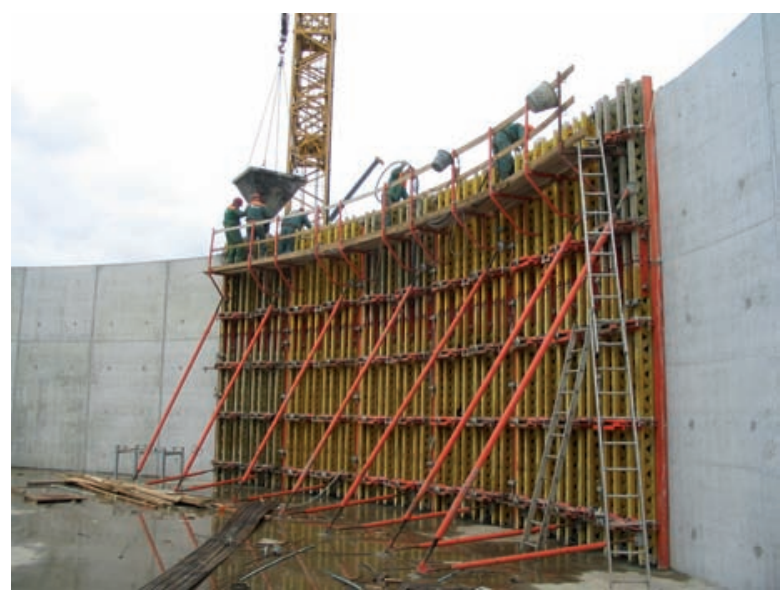

4 pav. Rezervuaro aukštos sienutès nenutrūkstamas betonavimas

Fig. 4. Continuous concreting of reservoir's high walls

\section{Išvados}

1. Žvirgždo skaldos atsparumo šalčiui markę ir jos tinkamumą hidrotechniniams betonams rekomenduojama nustatyti, ịvertinant silpnų dalelių kiekį ir jų atsparumą šalčiui. Žvirgždo skaldą su didesniu silpnų dalelių kiekiu (5-7 \%) rekomenduojama naudoti vandens valymo ịrenginių požeminių ir kitų konstrukcijų betonams, kurių neveikia kintamas vandens lygis ir nevyksta vandens perpylimas.

2. Betonų C25/30 ir žemesnių stiprio klasių nepralaidumą vandeniui rekomenduojama nustatyti pagal LST 1974:2005 metodą, o aukštesnių klasių betonų - pagal LST EN 12390-8.

3. Vandens nuotekų valymo įrenginių statyboms nenutrūkstamos betonavimo technologijos pritaikymas yra kompleksinis procesas, apimantis mokslinius tyrimus, projektavimą, naujų sprendimų bei technikos naudojimą. 
4. Aukštu sienučių betonavimo būdas turi būti parenkamas įvertinant vykdytojų patirtį, turimą techniką, statybos laiką ir terminus. Naudojama technologija turi užtikrinti projektines betono savybes ir jų stabilumą visoje konstrukcijoje.

5. Betonuojant aukštas rezervuarų sienutes reikia naudoti stabilių reologinių savybių betono mišinius, ịvertinti betonuojamų klodų skaičių, betonavimo intensyvumą, šviežiai sutankinto betono mišinio sèdimo deformacijas ir kietejjimo kinetiką pradiniu etapu.

\section{Literatūra}

ACI 207.2R-95. 1995. Effect of restraint, volume change and reinforcement on cracking of mass concrete. American Concrete Institute, Detroit. $26 \mathrm{p}$.

ACI 350R-6. 2006. Environmental engineering structures. American Concrete Institute, Farmington Hills. 484 p.

Corola Edvardsen Lyngby. 1996. Water penetrability and autogenous healing of separation cracks in concrete, BetonwerkFertigteil-Technik 11: 77-85.

Durable Concrete Structures. 1991. Swedish Concrete Association. Stockholm. $55 \mathrm{p}$.

Gutsch, A. W.; Laube, M. 2002. Crack control for the massive concrete structures of new central railway station in Berlin. Lisse, Abingdon, Exton (PA), Tokyo: A. A. Balkema publishers.

Hosoda, A.; Kishi, T. 2002. Crack resistant mechanism of expansive concrete in early ages. Lisse, Abingdon, Exton (PA), Tokyo: A. A. Balkema publishers.

Khatri, R. P.; Sirivivantnanon, V. 1997. Methods for the determination of water permeability of concrete, ACI Materials Journal: May-June, 257-261.

Nasir Amin M.; Jeong-Su Kim; Lee Y.; Jin-Keun Kim. 2008. Simulation of the thermal stress in mass concrete using a thermal stress measuring devize, Cement and Research 39 (2009). Elsevier, 154-164.

Seyed-Hassan Bagheri-Zadeh; Hyongkwan, K.; Hounsell, S.; Charles, R. W.; Soleymen, H.; King, M. 2007. Field study of concrete maturing methodology in cold water, Journal of Construction Engineering and Management (ASCE) 133(11): 827-835. doi:10.1061/(ASCE)0733-9364(2007)133:11(827)
Žiogas, V. 1995. Plastiškų ir liejų betono mišinių panaudojimas vandens valymo statinių betonams [Using plastic and flowing concrete mixes for water treatment plant concretes], iš 4-osios tarptautines konferencijos "Naujos statybinès medžiagos, konstrukcijos ir technologijos" medžiaga. Vilnius, $115-121$.

Žiogas, V. 1999. Hidrotechninių betonų savybių ir panaudojimo monolitineje statyboje ypatumų tyrimai [Analysis of properties hydrotechnical concretes and their using peculiarities in monolithic construction], iš 6-osios tarptautines konferencijos „Naujos statybinés medžiagos, konstrukcijos ir technologijos" medžiaga. Vilnius: Technika, 76-81.

Žiogas, V.; Juočiūnas, S. 2005. Monolitinių betoninių grindų įrengimo ypatumai naudojant plaušinį armavimą [Peculiarities of installation monolithic concrete floors using fiber reinforcement], iš Pažangioji statyba. Konferencijos pranešimy medžiaga. Kaunas: Technologija, 187-192.

Žiogas, V.; Juočiūnas, S. 2006. Pažangių technologijų taikymas specialios paskirties objektų statyboje [Application the Advanced Technology in Process of Construction the Special Objects], iš Pažangioji statyba. Konferencijos pranešimu medžiaga. Kauno technologijos universitetas. Kaunas, 177182.

Žiogas, V.; Juočiūnas, S. 2007. Continuity concreting technology of massive foundation slab on piles, in Modern Building Materials, Structures and Techniques: Selected Papers of the $9^{\text {th }}$ International Conference, May 16-18, 2007. Vilnius, Lithuania. Vilnius Gediminas Technical University, Lithuanian Academy of Science, International Association for Bridges and Structural Engineering, European Council of Civil Engineers. Vol. 1. Vilnius: Technika, 453-459 [ISI Proceedings].

Žiogas, V.; Žilinskaitè, A. 2005. Vandens valymo ịrenginių statybos technologijų analizè [Analysis of construction technologies of water treatment plants], iš Pažangioji statyba. Konferencijos medžiaga. Kaunas, 193-200.

Матвиенко, В. А.; Дрозд, Г. Я.; Затолокин, Н. Е. 1984. Коррозия цементного камня в очистных сооружениях. [Matvijenko, V. A.; Drozd, G. J.; Zatolokin, N. J. Corrosion of hardened cement paste in water treatment plants], Бетон $u$ железобетон 8: 40-41.

Шейкин, А. Е.; Чеховский, Ю. В.; Бруссер, М. И. 1979. Структура и свойства иементных бетонов [Sheikin, A. E.; Chechovskij, J. V.; Brusser, M. J. Structure and properties of cement concretes]. Москва: Стройиздат. $344 \mathrm{c}$.

\title{
HYDROTECHNICAL CONCRETE WITH LOCAL AGGREGATES AND THEM USING FOR MONOLITHIC STRUCTURES
}

\section{A. Žiogas, S. Juočiūnas, G. Žiogas}

\begin{abstract}
The article discusses the technological peculiarities of construction monolithic hydrotechnical concrete structures, use of local aggregates for producing special concretes, methods of determining water impermeability of concretes as well as the evaluation of the methods mentioned above. The article presents the requirements for the granulometric composition of aggregate mixes for the production of flowing concrete mixes used for the construction of monolithic hydrotechnical structures. The possibilities and expediency of using local crushed gravel with increased amounts of weak particles for hydro-
\end{abstract}


technical structures are discussed. The mass loss of weak particles is slight compared with the whole mass of aggregates, and the total mass loss of crushed gravel it occurs due to micro-cracks present in particles. The frost resistance mark of crushed gravel and its suitability for hydrotechnical concretes should be determined by evaluating the amount of weak particles and their frost resistance. The article discusses concrete impermeability data received by means of two methods (according to LST 1974:2005 and LST EN 12390-8 requirements). Theoretical water penetration depths have been calculated. Determination of water impermeability according to LST 1974:2005 is recommended for C25/30 and lower compressive strength class concretes with $\mathrm{W} \leq 8$. The LST EN 12390-8 water impermeability determina-tion method is recommended for C25/30 and higher compressive strength class concretes whose water impermea-bility mark is $\mathrm{W} \geq 8$. For the construction of certain hydrotechnical structures water impermeable concretes whose water penetration depth should not exceed $20 \mathrm{~mm}$ are recommended for use instead of the W6 and W8 concretes. Technological peculiarities and potential technological-organizational solutions for high walls of a water treatment plant have been discussed. The analysis of potential concreting methods of the reservoir's high walls has been made as well as that of the key parameters of the continuous concreting process and their interaction. Dependences for the estimation of continuous concreting volumes and permissible concreted segment lengths have been proposed by evaluating the beginning of the intensive formation structure of concrete, number of layers in the height of the concreted wall and concreting intensity.

Keywords: hydrotechnical concrete, local aggregates, concrete impermeability, structure of concrete, technology of continuous concreting, water treatment plants, reservoir's high walls.

Vigantas Antanas ŽIOGAS. Doctor, Associate Professor, Head of the Dept of Civil Engineering Technologies at Kaunas University of Technology (KTU). Research interests: massive building technologies, monolithic concrete floors arranging technologies, repair and strengthening technologies of concrete and reinforced concrete buildings, design composition of concrete mixes with special requirements, improvement the technology in monolithic building, research the special building technologies.

Svajūnas JUOČIUUNAS. Lecture of the Dept of Civil Engineering Technologies at Kaunas University of Technology (KTU). Research interests: technologies of installation monolithic concrete floors, optimization of construction processes.

Giedrius ŽIOGAS. Master of Civil Engineering. Civil Engineering AB Pramprojektas. 